\title{
Application of Adult Mesenchymal Stem Cells in Bone and Vascular Tissue Engineering
}

\author{
M. TRÁVNÍČKOVÁ ${ }^{1,2}$, L. BAČÁKOVÁ ${ }^{1}$ \\ ${ }^{1}$ Institute of Physiology of the Czech Academy of Sciences, Prague, Czech Republic, ${ }^{2}$ Second \\ Faculty of Medicine, Charles University, Prague, Czech Republic
}

Received November 29, 2017

Accepted June 19, 2018

On-line September 11, 2018

\section{Summary}

Tissue engineering is a very promising field of regenerative medicine. Life expectancy has been increasing, and tissue replacement is increasingly needed in patients suffering from various degenerative disorders of the organs. The use of adult mesenchymal stem cells (e.g. from adipose tissue or from bone marrow) in tissue engineering seems to be a promising approach for tissue replacements. Clinical applications can make direct use of the large secretome of these cells, which can have a positive influence on other cells around. Another advantage of adult mesenchymal stem cells is the possibility to differentiate them into various mature cells via appropriate culture conditions (i.e. medium composition, biomaterial properties, and dynamic conditions). This review is focused on current and future ways to carry out tissue replacement of damaged bones and blood vessels, especially with the use of suitable adult mesenchymal stem cells as a potential source of differentiated mature cells that can later be used for tissue replacement. The advantages and disadvantages of different stem cell sources are discussed, with a main focus on adipose-derived stem cells. Patient factors that can influence later clinical applications are taken into account.

\section{Key words}

Adult mesenchymal stem cells - Adipose-derived stem cells • Patient factors - Bone tissue engineering • Vascular tissue engineering

\section{Corresponding author}

M. Trávníčková, Department of Biomaterials and Tissue Engineering, Institute of Physiology of the Czech Academy of Sciences, Vídeňská 1083, 14220 Prague 4, Czech Republic. E-mail: Martina.Travnickova@fgu.cas.cz

\section{Introduction}

The current lifestyle of people, mainly in developed countries, is connected with so-called diseases of civilization. These diseases include a large group of cardiovascular diseases, obesity, hypertension, type 2 diabetes, tumor diseases, autoimmune diseases, osteoporosis, and psychiatric disorders. Nowadays, life expectancy is increasing, but many patients suffer from various age-related and degenerative diseases that are also influenced by current lifestyle (i.e. diet, exercise, smoking, alcohol, and mental stress). Age-related and degenerative diseases can be mitigated and sometimes prevented by changing the patient's habits, but pharmacotherapy often becomes necessary. However, in situations where pharmacotherapy is not sufficient, and severe complications occur, tissue replacement can be essential.

This review is focused on current and future ways to replace damaged bone and blood vessel tissues, especially with the use of suitable adult mesenchymal stem cells as a potential source of differentiated mature cells that can later be used for tissue replacement.

\section{Bone anatomy and physiology}

Bone is a compact tissue consisting of cancellous and cortical bone. Most of the bone tissue consists of extracellular matrix. The bone extracellular matrix is a mass of tissue (mainly organic component type I collagen and inorganic component hydroxyapatite) 
that surrounds and supports bone cells. Type I collagen provides tensile strength, and hydroxyapatite provides compressive stiffness (Reichert et al. 2016). Besides these main components, the extracellular matrix contains proteoglycans and glycosylated proteins. Each of the proteins has a role in influencing bone mineral deposition and in regulating the cell activity (for a review, see Clarke 2008).

There are four main types of cells in the bone tissue: i) osteoprogenitor cells, ii) osteoblasts, iii) osteocytes, and iv) osteoclasts. Osteoprogenitor cells are stem cells of mesenchymal origin capable of differentiation into osteoblasts. Osteoblasts are cells responsible for the synthesis and mineralization of the bone tissue. Their role is important during new bone formation and also in bone remodeling. Osteocytes are mature cells that occupy bone lacunae. Osteoclasts are multinucleate cells involved in bone resorption. In addition, hematopoietic cells are produced in the bone marrow.

Both in childhood and in adult age, the bone underlies the remodeling cues in a dynamic response to physiological influences and mechanical forces (Clarke 2008). Briefly, during the remodeling process, the old cells are resorbed (over a period of 2-3 weeks) and new bone tissue is formed (over a period of 2-3 months) to keep mineral homeostasis stable (Reichert et al. 2016). In the first phase, osteoclast formation and activation is regulated by receptor activator NF-kB ligand (RANKL), osteoprotegrin, proteins of the interleukin family, colonystimulating factors (CSF), parathyroid hormone, 1,25-dihydroxyvitamin D, and calcitonin (Clarke 2008, Martin and Seeman 2008). Subsequent bone tissue formation is influenced and regulated by bone matrixderived factors, such as insulin-like growth factor (IGF) I and II, acidic and basic fibroblast growth factor (FGF), transforming growth factor $\beta$ (TGF- $\beta$ ) 1 and 2 , bone morphogenetic proteins (BMPs) 2, 3, 4, 6, and 7, plateletderived growth factor (PDGF), and potentially other molecules (Bonewald et al. 1990, Clarke 2008, Martin and Seeman 2008).

\section{Pathophysiology of degenerative bone damage}

Osteoarthritis (and one of its important types, i.e. osteoarthrosis) is an age-associated chronic degenerative disorder of cartilage and bone that affects many patients all over the world. The hip and knee joints are most often affected, due to loading during activities of daily living (Kutzner et al. 2010). The risk factors of osteoarthritis include age, microtrauma injury damage, an inflammation insult, obesity, or genetic predispositions (Loeser et al. 2016). Although the loss of articular cartilage has been reported as the first set of changes, it is now clear that a second set of changes also affects subchondral bone, bone marrow, synovium, menisci, ligaments and periarticular muscles (for a review, see Man and Mologhianu 2014).

In osteoarthritic conditions, the chondrocytes are no longer able to maintain homeostasis between synthesis and degradation of cartilage extracellular matrix (Heijink et al. 2012). First, the damaged cartilage changes its mechanical properties, and it becomes thinner and more fragile. Over a period of time, the cartilage thins to total destruction, and the subchondral bone is revealed by this process. Changes in the bone tissue result in the loss of trabecular bone, bone marrow lesions, abnormal remodeling, and sclerotic changes. These changes are probably influenced by growth factors that are released from the synovial fluid. It is still not clear whether the process of cartilage and subchondral damage occurs simultaneously or separately (Man and Mologhianu 2014). Besides these changes, it is possible to detect hyperplasia and inflammation of the synovial membrane (Brandt et al. 2008), the presence of proinflammatory cytokines and damage of the menisci (Pauli et al. 2011).

Osteoarthritis is a widespread degenerative joint disorder, which can be alleviated in its earlier stages by medication; however, in its later stages a total joint replacement can be desirable.

\section{Vascular anatomy and physiology}

Blood vessels (i.e. arteries and veins of various diameters) are composed of three concentric layers: tunica intima, tunica media, and tunica adventitia. The thickness of each of the layers varies among individual blood vessel types.

Tunica intima (intima) is the inner layer, which comes into direct contact with the blood flow. This layer is composed of a monolayer of polygonal endothelial cells (ECs), the basal membrane, connective tissue, and there may also be a supportive internal elastic lamina (in the arterial wall).

Tunica media (media) is the middle layer of blood vessels. It is composed of vascular smooth muscle cells (VSMCs) and fibroblasts, each of them produce the extracellular matrix. The extracellular matrix is composed mainly of elastic and collagen fibres. 
Tunica adventitia (adventitia, tunica externa) is the external layer of blood vessels. The adventitia is composed of fibroblasts, collagen connective tissue and, in arteries, also of external elastic lamina. The adventitia is also a source of pericytes (in capillaries and microvessels) and adventitial cells (around large vessels), which are, in fact, multipotent mesenchymal stem cells able to differentiate into various cell types (Corselli et al. 2012).

Physiologically, the endothelial layer is continuous and intact, and is composed of mature ECs. The properties of ECs are as follows: i) non-proliferating, ii) non-thrombogenic, iii) non-immunogenic, and iv) rich in secreting various molecules. The secreted molecules can regulate the blood flow (e.g. endothelin, angiotensin, NO, prostacyclins), hemocoagulation (e.g. von Willebrand factor, tissue factor, trombomodulin, prostacyclins), the growth of vascular smooth muscle cells (e.g. fibroblast growth factor - FGF, platelet-derived growth factor PDGF, heparin, transforming growth factor - TGF, epidermal growth factor - EGF), and the production of extracellular matrix, particularly heparin-like glycosaminoglycans, which keep the VSMCs in their quiescent, non-proliferative and differentiated contractile phenotype (Pometlová et al. 2015, for a review, see Bačáková et al. 2014).

\section{Pathophysiology of degenerative vascular damage}

The pathophysiology of vascular damage is usually associated with a dysfunction of endothelial cells. Atherosclerosis is a frequent chronic inflammation of the intima layer, in which the etiology of the endothelial dysfunction is multifactorial. There are mechanical insults, e.g. hypertension, and chemical insults, e.g. low density lipoproteins (LDL), glucose, homocysteine, uric acid, oxygen radicals, which are responsible for pro-vasoconstrictive, pro-coagulative, pro-inflammatory, and pro-proliferative pathways (Pometlová et al. 2015).

The increased release of biologically-active molecules from the endothelium (PDGF, FGF, and EGF) stimulates VSMCs in proliferation, and abnormal migration from the media layer into the subendothelial layer. At the same time, the VSMCs lose their contractile proteins (alpha-actin, myosin heavy chain), and their metabolism in cell organelles is focused more on proteosynthesis. In other words, VSMCs gain a dedifferentiated phenotype, referred to as synthetic phenotype (Sung et al. 2005, Fager et al. 1989).

These mechanisms lead to thickening of the arterial wall. The lumen of the artery becomes thinner and restricts the blood flow. The atheroma plaque can become unstable, and after a hemocoagulation cascade is activated on its surface, it can cause thrombotic occlusion in the damaged artery. An embolism from unstable atherosclerotic plaque can also occur. Although prevention and pharmacological treatment are often successful, replacement is sometimes unavoidable, due to irreversible damage to the artery (Chlupáč et al. 2009).

\section{Regenerative medicine, tissue engineering and biomaterials}

Regenerative medicine is a multi-disciplinary field that combines findings from biology, chemistry, physics, medicine, and computer science. The aim of this recently-established field of medicine is to deal with regenerating and replacing human cells, tissues and even organs that have been damaged by degenerative diseases, by trauma or by other causes.

Tissue engineering is a promising subfield of regenerative medicine. Although autologous tissue is still considered to be the best-accepted material for tissue replacement, it can be obtained in limited quantities only. In addition, harvesting this tissue can cause higher morbidity of the patient. Tissue engineering involves studies of biologically compatible materials that can be implanted into the human body. The purpose of tissue engineering is either to ameliorate currently-used biomaterials or to create new biomaterials. The fabricated biomaterials can be seeded with mature cells or with stem cells. Seeding with the patient's autologous cells seems to be an advantageous way to accelerate the integration of implants into the human body, since there is a lower immune response of the body.

Biomaterials are natural or synthetic materials, where the term "bio" signals the interaction between materials and biological units (i.e. cells). These natural materials can be categorized according to their origin: protein origin (e.g. silk, collagen, fibrin) and polysaccharide origin (e.g. hyaluronic acid, alginate, chitosan). Similarly, synthetic biomaterials include polymers (e.g. polylactide, polycaprolactone, polyethylene glycol) and ceramics (e.g. hydroxyapatite, bioactive glass, calcium phosphate, zirconia) (for a review, see O’Brien 2011, Alaribe et al. 2016). From the point of view of clinical use, biomaterials can be categorized as either biodegradable or stable. The term "scaffold" refers to a fabricated biomaterial in 3D architecture before the cells have been added (O’Brien 2011). 


\section{Stem cells}

Stem cells are generally defined as clonogenic cells capable of both self-renewal and multilineage differentiation into phenotypically mature cells (Weissman 2000).

The degree of "potency" of stem cells, i.e. the range of differentiation options for generating different cell types, is used to classify stem cells as follows: i) totipotent cells, ii) pluripotent cells, iii) multipotent cells, and (iv) unipotent cells (for a review, see Bissels et al. 2016, Bacakova et al. 2018). Totipotent cells are capable of generating all cells, including extraembryonic cell types (e.g. zygote). Pluripotent cells are able to generate all body cells, including germ cells (e.g. embryonic stem cells, and induced pluripotent stem cells). Multipotent cells are capable of generating all or at least some tissue cell types (e.g. hematopoietic stem cells, mesenchymal stem cells). Unipotent cells are able to generate a single cell type (e.g. spermatogonial stem cells) (for a review, see Bissels et al. 2016, Bacakova et al. 2018).

Besides categorizing them by the degree of "potency", stem cells can be classified according to their source (Table 1).

Table 1. Classification of stem cells according to their origin and their source.

\section{Origin of stem cells Source of stem cells}

Embryonic stem cells

Fetal stem cells

Adult stem cells

Induced pluripotent stem cells morula, blastocyst (Gaskell et al. 2016)

fetal tissue (O’Donoghue and Fisk 2004), placenta (Igura et al. 2004), amniotic fluid (In’t Anker et al. 2003), Wharton jelly (Wang et al. 2004), umbilical cord blood (Kern et al. 2006)

bone marrow (Wakitani et al. 2002), adipose tissue (Zuk et al. 2001, Zuk et al. 2002), dental pulp (Stanko et al. 2018), skeletal muscle (Hinken and Billin 2018), skin (Ojeh et al. 2015), peripheral blood (Esposito 2018), liver (Willemse et al. 2017), neural tissue (Zhang et al. 2016), heart (Klopsch et al. 2017), intestine (Barisas and Stappenbeck 2018), cancer tissue (De Francesco et al. 2018)

differentiated mature somatic cells (Takahashi and Yamanaka 2006)
Stem cells are a very promising source for tissue engineering, as they have higher proliferation capacity, a lower tendency to senescence, and they withstand more passages in a cell culture than mature differentiated cells (for a review, see Atala 2005). Their multilineage potential can be used in differentiation into a desired phenotype, and their paracrine secretion of various growth factors can have a positive influence on the cells around (for a review, see Gnecchi et al. 2008). However, there are many ethical and regulatory constraints surrounding the use of stem cells, especially totipotent and pluripotent stem cells, i.e. cells derived from human embryonic or fetal tissues. However, adult stem cells (e.g. mesenchymal stem cells, hematopoietic stem cells, endothelial progenitor cells, etc.) can easily be harvested, and their use in autologous or allogenous therapeutic applications has been widely discussed (Asahara et al. 2000).
The following sections will cover all four main groups of stem cells, with special emphasis on adult mesenchymal stem cells - adipose tissue-derived stem cells.

\section{Embryonic stem cells}

Embryonic stem cells (ESCs) are defined as cells derived from the inner cell mass of pre-implantation stage blastocyst, 5-7 days after fertilization (Gaskell et al. 2016). These cells have great potential for regenerative therapies because of their pluripotency (i.e. their ability to differentiate into a cell of any type in the human body) and their limitless proliferation capacity. Although the therapeutic potential of ESCs could be high, the procedure for obtaining them is difficult due to the ethical law in many countries, and the harvested cells are available only in limited quantities. Moreover, as the pluripotent potential of these cells is so high, the potency 
to teratoma formation also seems to be non-negligible (Ben-David and Benvenisty 2011).

\section{Fetal stem cells}

Fetal stem cells (FSCs) are multipotent stem cells of various origins. Among FSCs, hematopoietic and mesenchymal stem cells have been studied most intensively. These stem cells can be harvested from the fetal blood, or from the fetal bone marrow. Compared to adult hematopoietic and mesenchymal stem cells, FSCs have better intrinsic homing and engraftment, greater multipotency and lower immunogenicity (O’Donoghue and Fisk 2004). In spite of these advantages, harvesting stem cells from fetal tissues can be controversial.

In recent years, comparatively harmless new sources of fetal multipotent stem cells have been studied, namely extrafetal tissues, such as placenta, amniotic fluid, Wharton jelly, umbilical cord blood, decidua basalis, decidua parietalis (Igura et al. 2004, In't Anker et al. 2003, In’t Anker et al. 2004, Kim et al. 2004, Kögler et al. 2004, Wang et al. 2004, Yang et al. 2004). In some papers, these are treated as adult stem cell sources, as the origin of the tissue is both maternal and fetal.

Nowadays, stem cells of umbilical cord blood origin can be banked for future allogenic or autologous cellular therapies, especially for umbilical cord blood transplantation in hematologic disorders (for a review, see Brunstein and Wagner 2006, Ballen et al. 2013).

\section{Adult mesenchymal stem cells}

Mesenchymal stem cells (MSCs) are a heterogeneous subset of plastic-adherent fibroblast-like cells that can be obtained from various adult tissues, e.g. bone marrow, adipose tissue, peripheral blood, skeletal muscle, and others (Wuchter et al. 2016).

However, the nomenclature of MSCs is not uniform. Caplan (1991) established the term "mesenchymal stem cells". In the literature, there are various names which refer to the same cells. These names - marrow stromal cells, multipotent stromal cells, mesodermal stem cells, mesenchymal stem cells, mesenchymal stromal cells, medicinal signaling cells refer to the origin of the cells, or to their current use in a given study (Caplan 2017). As mesenchymal stem cells are nowadays mostly used to home in on the sites of injuries or diseases and secrete bioactive factors, Caplan suggested in 2017 that the term "medicinal signaling cells" should be used preferentially.

According to the current definition, MSCs are multipotent cells that are able to differentiate into cells of mesodermal lineages, e.g. bone, cartilage and adipose cells (Pittenger et al. 1999, Uccelli et al. 2008, Wuchter et al. 2016). Furthermore, their differentiation capacity is broader in in vitro cultures, depending on the chemical composition of the medium, the mechanical properties of the scaffold, and the dynamic cultivation conditions.

Nowadays, bone marrow stem cells (BMSCs) and adipose-derived stem cells (ASCs) are most widely studied among MSCs, and they are being tested in many in vitro and in vivo studies on regenerative medicine and cell-based therapy. Current and previous clinical trials have been registered by the U.S. National Institutes of Health (https://www.clinicaltrials.gov).

\section{- Bone marrow stem cells}

Bone marrow stem cells (BMSCs) were the first MSCs to be successfully isolated, characterized in detail and used widely in regenerative medicine as a source of adult stem cells. Bone marrow is usually aspired from the sternum or from the pelvic area as a diagnostic method for blood diseases or during a bone marrow transplantation procedure. This procedure is uncomfortable and painful for patients, and they produce only limited yields of isolated BMSCs. Nevertheless, the multipotent potential and the adult origin of BMSCs ensure that they are considered as a suitable source at least for bone and cartilage tissue engineering. There have been studies using the direct effect of BMSCs on cartilage regeneration in osteoarthritic knees (Wakitani et al. 2002, Yamasaki et al. 2014) and in wound healing (Wu et al. 2007, Chen et al. 2008). The interaction of BMSCs with a suitable scaffold, e.g. with silk (Meinel et al. 2005) or alginate (for a review, see Sun and Tan 2013), for repairing bone and cartilage has also been studied.

A detailed characterization of BMSC behavior, their differentiation pathways, and their genome will later help us to understand the behavior of MSCs. In addition, the characteristics of newly-described types of MSCs can be compared with these undoubtedly promising adult stem cell sources.

\section{- Adipose-derived stem cells}

Adipose-derived stem cells (ASCs) are stem cells of adult origin that were first identified and described in 2001 as an alternative source of autologous or allogenous MSCs for tissue engineering (Zuk et al. 2001). In many patients, ASCs are more abundant than BMSCs, and subcutaneous adipose tissue is easily 
accessible. ASCs can be harvested via liposuction under local anesthesia. The tumescent liposuction procedure is a painless and reasonably comfortable way for patients to provide enough autologous stem cells. BMSCs and ASCs have a similar multilineage differentiation potential (Zuk et al. 2002, Strem et al. 2005), while the yields of stem cells and the proliferation capacity were observed to be higher for ASCs (Kern et al. 2006).

In recent years, adult stem cell research has made huge progress in the field of cell-based therapy and in regenerative medicine in general. The ASC secretome includes active molecules such as vascular endothelial growth factor (VEGF), transforming growth factor beta (TGF- $\beta$ ), basic fibroblast growth factor (bFGF), granulocyte colony-stimulating factor (G-CSF), interleukin 6 and 8 (IL-6, IL-8), nerve growth factor (NGF), hepatocyte growth factor (HGF), insulin-like growth factor-1 (IGF-1), brain-derived growth factor (BDNF), and glial-derived growth factor (GDNF) (for a review, see Banyard et al. 2015). The future of ASCs offers direct use of their secretion of trophic factors, and also their multilineage differentiation potential (Frese et al. 2016, Li et al. 2016). However, there still remain some barriers that have to be overcome; i) a precisely-defined source population of ASCs, ii) isolation procedures according to regulatory clinical standards, iii) better understanding of the behavior of ASCs in their niche and in interaction with scaffolds, iv) an evaluation of the safety and the effectiveness of clinical applications, and v) long-term follow-up studies on the consequences in patients (Banyard et al. 2014, Li et al. 2016).

Sources, isolation procedure and characterization of ASCs There are various deposits of adipose tissue from which ASCs can be isolated. These deposits can be classified as i) superficial subcutaneous sources and ii) deep peri-organ adipose deposits. Due to their easier accessibility, subcutaneous sources are widely used, especially via the liposuction procedure.

Subcutaneous adipose tissue consists of mature adipocytes and so-called stromal vascular fraction (SVF). SVF is a heterogeneous cell population of fibroblasts, pericytes, pre-adipocytes, endothelial cells, blood cells and proper ASCs (Varma et al. 2007, Zimmerlin et al. 2010).

Approaches to the isolation of ASCs from lipoaspirate are usually based on digesting the adipose tissue with collagenase type I. Then SVF is obtained, and the cells are seeded in a growth medium into culture flasks (Estes et al. 2010).

In subsequent cell passages, it is necessary to perform phenotypical characterization of isolated cells to prove their mesenchymal origin. According to the International Society for Cellular Therapy, ASCs in a culture retain the following surface markers: CD90, CD73, CD105, and CD44 (>95 \%), and they lack CD45 and CD31 (<5\%) (Bourin et al. 2013). In addition, advice has been given to test their multilineage potential for adipocytic, chondroblastic and osteoblastic differentiation in media supplemented by growth factors and other specific additives.

Current and potential clinical applications of ASCs Clinical applications of ASCs can be divided into i) direct use of ASCs and their secretome, and ii) differentiation of ASCs into desired mature cells.

For the direct use of ASCs, cell-assisted lipotransfer (CAL) has been used in plastic surgery and esthetic medicine for filling and augmentation purposes. CAL combines freshly isolated autologous SVF with an injection of intact lipoaspired adipose tissue (Yoshimura et al. 2008, Li et al. 2016).

As has been discussed above, ASCs secrete a large variety of growth factors and other proteins involved in the trophic effects of ASCs on the protection, healing, vascularization, survival and differentiation of a variety of tissues (Salgado et al. 2010). The potential for accelerated treatment of chronic limb defects and diabetic wounds is therefore another example of the direct autologous application of ASCs or SVF (Collawn et al. 2012, Strong et al. 2015).

ASCs have also been reported to modulate an immune response and inflammatory signs during immune diseases (Singer and Caplan 2011). For example, ASCs reduced the immune response in experimental colitis (Gonzalez et al. 2009), experimental autoimmune diabetes (Bassi et al. 2012), graft-versus-host disease (Yanez et al. 2006) and rheumatoid arthritis (Gonzalez et al. 2010).

Due to the mesodermal origin of the cells, ASCs seem to be suitable and predetermined for bone and cartilage tissue regeneration. There have been several studies in which the intraarticular or periarticular injection of SVF or ASCs was applied to support cartilage regeneration in patients suffering from osteoarthritis, chondromalacia, osteonecrosis of the femoral head, or a meniscus tear. The results have 
suggested potential benefits of SVF or ASCs in various orthopedic applications (Pak et al. 2017). ASCs can also be used in bone tissue engineering to repair bone defects. Lendeckel et al. (2004) reported the treatment of a calvarial defect using a combination of autologous ASCs and fibrin glue. Another approach to the use of ASCs in bone repair is their osteogenic differentiation into osteoblasts, which can be seeded into a suitable scaffold. Subsequently, this cell-populated scaffold would be transplanted into the human body to replace damaged bone or a damaged joint (Awad et al. 2004, Levi and Longaker 2011).

Current prospects in vascular tissue engineering offer the possibility to differentiate ASCs towards smooth muscle cells or endothelial cells. Although both ASCs and endothelial cells are of mesodermal origin, the differentiation of ASCs into ECs is considered difficult and resembling the trans-differentiation of ASCs into cells of another germ layer, e.g. into keratinocytes, which are of ectodermal origin. The main reason for the difficulty is the polarization of endothelial cells. These cells have apical-basal polarity, i.e. functional specialization of their luminal and basolateral membranes (Roberts and Sandra 1993), and planar polarity, which is important for endothelial cell movement, proliferation, angiogenesis and the response to shear stress (McCue et al. 2006). By contrast, ASCs are mesenchymal cells, i.e. they are mesodermal cells that lack polarity. Therefore, an alternative approach is to utilize the paracrine secretion of growth factors from ASCs and to co-culture them with endothelial cells in order to accelerate their growth and phenotypic maturation
(Merfeld-Clauss et al. 2010). These differentiated cells would then be suitable for vascular prosthesis seeding.

In addition to these applications, there have been numerous studies focused on various areas of regenerative medicine, such as hair regeneration (for a review, see Jin and Sung 2016), peripheral nerve regeneration (di Summa et al. 2010), cardiovascular repair (for a review, see Madonna and De Caterina 2010, Brenner et al. 2016), pancreatic repair (Lin et al. 2009) and hepatic repair (Banas et al. 2009).

Patient factors In recent years, as the number of studies using ASCs in regenerative medicine has been rising, patient factors seem to be very important. So far, there have been several studies focusing on the association between ASC viability and various donor factors. Subsequent proliferation and differentiation capacity, which can be patient-dependent, has also been a topic of interest.

The main factors that can vary from patient to patient (i.e. gender, age, BMI, harvest site) are summarized in Table 2. Varghese et al. (2017) analyzed 41 papers in which some of the patient factors showed significant differences. Besides these main factors, there are some studies that have suggested a potential influence of radiotherapy, chemotherapy, hormonal treatment, smoking, hypertension, diabetes mellitus, or renal disease on the properties of isolated ASCs (Varghese et al. 2017).

There are also factors resulting from ASC harvesting and isolation methods that can influence the quality and the further use of isolated ASCs (Table 2).

Table 2. Main factors that influence the yield, proliferation and differentiation of ASCs.

Factors Differences

\begin{tabular}{|c|c|c|}
\hline Patient & Gender & no significant differences so far (Varghese et al. 2017) \\
\hline \multirow[t]{2}{*}{ factors } & Age & $\downarrow$ yields, proliferation and differentiation within $\uparrow$ age of donor (Varghese et al. 2017) \\
\hline & $B M I$ & $\begin{array}{l}\downarrow \text { viable cells in some studies within } \uparrow \text { BMI of donor, significant negative correlation } \\
\text { between BMI and differentiation (Varghese et al. 2017) }\end{array}$ \\
\hline \multirow[t]{3}{*}{$\begin{array}{l}\text { Procedure } \\
\text { factors }\end{array}$} & $\begin{array}{l}\text { Harvesting } \\
\text { procedure }\end{array}$ & $\begin{array}{l}\text { yields are almost the same via liposuction and excision procedures (von Heimburg } \\
\text { et al. 2004, Torio Padron et al. 2010) } \\
\text { liposuction is more comfortable for donors }\end{array}$ \\
\hline & Harvest site & $\begin{array}{l}\uparrow \text { yields from lower abdomen and thigh site } \\
\uparrow \text { stemness and multipotency from superficial adipose tissue (Varghese et al. 2017) }\end{array}$ \\
\hline & $\begin{array}{l}\text { Liposuction } \\
\text { pressure }\end{array}$ & $\begin{array}{l}\uparrow \text { yields, proliferation or differentiation within } \downarrow \text { negative pressure (Mojallal et al. } \\
\text { 2008, Chen et al. 2017, Przekora et al. 2017) }\end{array}$ \\
\hline
\end{tabular}


Induced pluripotent stem cells

Induced pluripotent stem cells (iPSCs) were first described by Takahashi and Yamanaka (2006). The key step in iPSC production is the process of reprogramming mature differentiated cells into an embryonic-like state.

The advantages of iPSCs seem to be i) their pluripotency, ii) their potential for gene correction, and iii) the fact that they are a relatively easily accessible source of autologous cells. However, Riggs et al. (2013) studied the differences in transcriptomes between iPSCs and in vitro produced tumor cells from the same fibroblast origin. They found a significant number of similar genes that were present either in iPSCs or in tumor cells. These results suggested similar processes while inducing pluripotency and tumorigenicity in mature cells. Hence, similarly to pluripotent ESCs, the potential to form ectopic and tumorigenic tissue seems to be non-negligible, and needs to be further investigated in detail (Ben-David and Benvenisty 2011).

\section{Differentiation of mesenchymal stem cells towards mature cells}

Cells in in vitro cultures are influenced by various stimuli. In general, depending on the cell type, various stimuli can support the cells in changes of morphology, secretome, proliferation rate, and differentiation (Fig. 1). If the culture conditions are not suitable for a specific cell type, apoptosis cascades can be triggered. Stem cells are particularly responsive to every stimulus, as it is natural for them to receive signals in vivo in the human body. The role of these signals is either to retain them in "stem condition" or to trigger differentiation into the desired phenotype. Different culture conditions can be used separately, or can be combined to multiply these effects.

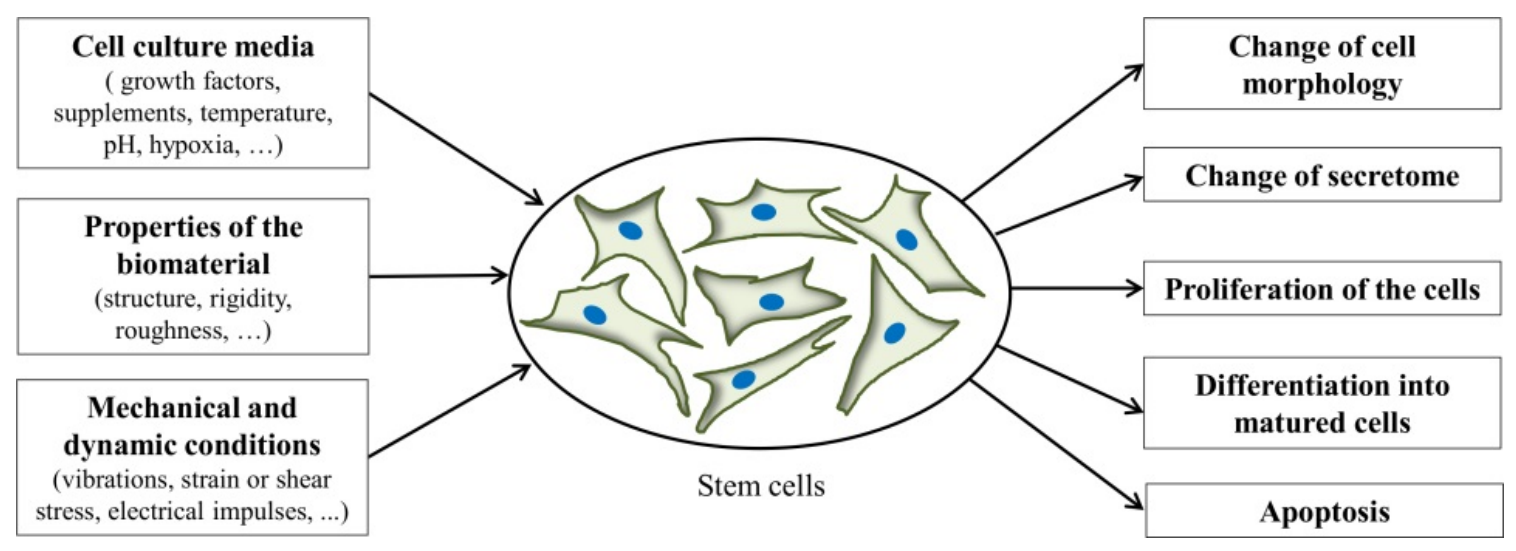

Fig. 1. The culture conditions that influence cells in in vitro culture and possible subsequent responses of the cells.

\section{Osteogenic differentiation}

Because of their mesodermal origin, osteogenic differentiation in adult MSCs has been studied in detail. This origin suggests that it is a relatively easy type of differentiation, especially if these cells are isolated from the bone marrow.

The usual composition of the differentiation medium consists of a basal medium, a fetal bovine serum, antibiotics, ascorbic acid, $\beta$-glycerophosphate, and dexamethasone in various concentrations (for a review, see Liao and Chen 2014). Variably, the medium can also be supplemented with vitamin D, L-glutamin, transforming growth factor-beta, and bone morphogenic proteins (for a review, see Vater et al. 2011).

Osteogenic differentiation can also be supported by suitable biomaterial properties: i.e. adhesivity, stiffness, nanocrystalline structure and degradability (for a review, see Murphy et al. 2014). In addition, the 3D structure of scaffolds seems to be more attractive for the cells, as it simulates the natural niche of cells.

In recent years, research has focused on dynamic conditions of in vitro cultures. For better simulation of the mechanical cues occurring in the human body, cyclic equiaxial stretching (Virjula et al. 2017) or vibration loading (Tirkkonen et al. 2011, Zhou et al. 2011) have been applied to MSCs. The results have shown faster and higher osteogenic differentiation, while combining appropriate mechanical conditions with a suitable scaffold architecture and a suitable composition of the medium.

\section{Smooth muscle cell differentiation}

Differentiation into smooth muscle cells depending on the composition of the media has already 
been performed successfully. There are various growth factors and molecules that can support differentiation. Transforming growth factor beta 1 (TGF-beta1) was one of the first factors shown to have a positive influence on the formation of the alpha-actin, calponin, caldesmon, and myosin-heavy chain protein structures that are involved in smooth muscle cell differentiation. Studies have been made not only of TGF-beta1, but also of thromboxane A2, angiotensin II, sphingosylphosphorylcholin, ascorbic acid, platelet-derived growth factor (PDGF), epidermal growth factor (EGF), and bone morphogenetic protein 4 (BMP4), in various combinations and concentrations (Narrita et al. 2008, Kim et al. 2009, Harris et al. 2011, Brun et al. 2015). Nevertheless, it should be taken into account that TGF-beta1 also supports the transition of fibroblasts to myofibroblasts, which are associated with various diseases, such as systemic sclerosis (Lafyatis 2014), pulmonary hypertension (Chen et al. 2014) with subsequent right ventricular remodeling (He et al. 2017), and particularly tumor diseases, such as melanoma (Kodet et al. 2018) or breast carcinoma (Kojima et al. 2010). The proper differentiation effect of TGF-beta1 towards smooth muscle cell phenotype should be simultaneously supported by appropriate scaffolds and particularly by appropriate mechanical stimulation.

Smooth muscle cell differentiation is an aspect of "soft tissue engineering", and is supported by "soft" biomaterials. Basic components of extracellular matrix, i.e. type I collagen, poly-L-lysin or fibronectin (Cooper et al. 2011, Sgarioto et al. 2012, Wei et al. 2014), are used to compose or at least to coat biomaterials for faster cell adhesion and also for cell differentiation (Filová et al. 2014).

In the human body, blood vessels are exposed to permanent cyclic strain stress with an average frequency of 60 heartbeats per minute. These conditions have a positive influence on the differentiation of progenitor cells. Cyclic strain stress of amplitudes between 5 and $10 \%$ and with a frequency of $0.5-1.5 \mathrm{~Hz}$ supports the differentiation pathways of stem cells into smooth muscle cells (Shimizu et al. 2008, Rothdiener et al. 2016).

Similarly to osteogenic differentiation, the differentiation of stem cells can be even faster and more successful when the effects of media composition, the properties of the biomaterial, and dynamic culture conditions are combined.

\section{Substitutes used in bone tissue engineering}

Many patients suffer from degenerative or traumatic diseases of the skeletal system. Current therapies in bone diseases are focused on autografts and allografts, or on the implantation of metal- or ceramicbased implants (Reichert et al. 2016). The strategies for fabricating an appropriate biomaterial are directed at tissue conduction and induction. Tissue conduction refers to the migration of cells of a given tissue and blood vessel formation that can be reached in 3D scaffolds. An induction strategy refers to support for the proliferation and differentiation of progenitor cells to a desired phenotype (Reichert et al. 2016). So far, bone grafts remain the best choice concerning osteoconductive and osteoinductive properties, i.e. they stimulate the ingrowth of osteoblasts inside the graft material and, at the same time, they induce differentiation of local stem cells into osteoblasts (García-Gareta et al. 2015) However, these grafts can be harvested only in limited quantities, and donor site morbidity also has to be taken into account.

In implant orthopedic surgery, metallic biomaterials are still used as the "gold standard" for total joint replacements in patients suffering from osteoarthritis. Stainless steels, cobalt-based alloys, titanium alloys, and modifications to these alloys, have been widely used, though some of their physical and biological properties differ from those of healthy bone tissue (e.g. their Young's modulus, biocompatibility, osseointegration, corrosion, and wear) (for a review, see Saini et al. 2015). Recently, some other metals have been involved in alloy preparation. Ni-Ti shape-memory alloys, magnesium, tantalum, zirconium and silver have been studied, due to their suitable physical, mechanical, chemical or biological properties (for a review, see Chen and Thouas 2015).

Currently, bone tissue engineering is focused on autologous adult stem cells in combination with an appropriate scaffold aimed at mimicking and simulating the properties of the natural bone tissue (Dawson et al. 2008, Reichert et al. 2016). The scaffold can serve as a conductive and inductive microenvironment to support the proliferation and differentiation of stem cells into osteoblasts and osteocytes, and potentially also small blood vessel formation (for a review, see Arvidson et al. 2011). 


\section{Substitutes used in vascular tissue engineering}

Vascular grafting is a surgical procedure in which a damaged or occluded vessel is replaced by an autograft, an allograft, or a synthetic prosthesis. Human grafts can be of venous or arterial origin. They usually bestow good mechanical properties, high infection resistance and low antigenicity for patients. Although autografts are the first choice when replacing small or medium caliber vessels, smaller grafts less than $6 \mathrm{~mm}$ in diameter usually fail within 5 years after surgery (Leon and Greisler 2003). Moreover, autografts and allografts are available only in limited quantities, due to the age of the patients and donor site morbidity.

Until now, vascular tissue engineering has used scaffolds with a polymer-based origin. Polymer-based biomaterials are elastic, so they mimic the physical properties of vessels. Various modifications of polyethylene terephthalate (PET) and polytetrafluoroethylene (PTFE) are used in blood vessel replacements (Kannan et al. 2005, Chlupáč et al. 2009). These prostheses are non-degradable, and they are fabricated to be porous. However, possible disadvantages of synthetic vascular prostheses are limited incorporation, graft rejection, risk of infection, dilatation over time, and surface thrombogenicity (Chlupáč et al. 2009).

Non-degradable PET and PTFE are widely used, and there is a tendency to fabricate advanced bioartificial degradable scaffolds. These scaffolds (e.g. polyurethane, polylactide, polycapronolactone, and polyglycolide) could serve as a temporary structure for attaching the cells. The attached cells could start to produce new layers of the blood vessel, while the degradable scaffold would slowly resorb (for a review, see Venkatraman et al. 2008). However, these biomaterials have inadequate mechanical properties (Ravi et al. 2009), and the scaffold still degrades in the human body more rapidly than the blood vessel forms.

Another approach in vascular tissue engineering is to use biologically-based decellularized vessels of xenogeneic, e.g. porcine origin (Badylak 2004). These grafts can be harvested in sufficient quantities. The optimal decellularization procedure can offer biocompatible scaffolds in which the properties are very similar to those of autografts, while the immunogenicity is very low due to the absence of xenogenous cells (for a review, see Tapias and Ott 2014). Furthermore, decellularized grafts can later be ameliorated by coating them with type I collagen, fibrin or other proteins of the extracellular matrix that support cell adhesion, proliferation and differentiation (Filová et al. 2014).

In order to improve the biocompatible properties of vascular replacements, there are strategies that attempt to combine autologous cells of different origin with either decellularized or synthetic material-based prostheses (Harris et al. 2011, Quint et al. 2012). This combination could provide high biocompatibility of the graft, suitable mechanical properties similar to those of autografts and, last but not least, easier availability of the grafts in sufficient quantities (for a review, see Murphy and Atala 2013).

\section{Our experience with stem cells}

Different proliferation and osteogenic potential of ASCs influenced by fibroblast growth factor 2 (FGF2)

Osteogenic differentiation is influenced by the composition of the medium. ASCs are usually grown in a basal medium supplemented by growth factors. The addition of FGF2 can influence the subsequent use of ASCs in bone tissue engineering. It has been reported that, in low concentrations, FGF2 supports a proliferative state of the cells rather than a differentiated state of the cells (Hu et al. 2013). Moreover, pre-treatment with FGF2 plays a beneficial role in subsequent osteogenic differentiation (Lim et al. 2016). However, the role of FGF2 during osteogenic differentiation is ambiguous, and the results vary from study to study. Hu et al. (2013) reported a negative effect of FGF2 on osteogenic differentiation; however, Park (2014) reported a positive effect of FGF2 on the expression of bone morphogenetic protein receptors. Recently, Simann et al. (2017) presented new findings that FGFs (i.e. FGF1 and FGF2) prevent osteogenic differentiation of BMSCs via ERK 1/2 signaling.

In our experiment, we studied the impact of FGF2 on the proliferation and osteogenic differentiation of ASCs. The cells in the second passage were cultured in Dulbecco's Modified Eagle Medium (DMEM), supplemented with $10 \%$ fetal bovine serum (FS) and $10 \mathrm{ng} / \mathrm{ml}$ of FGF2. When the cells reached $80 \%$ confluence, the basal medium was replaced by osteogenic medium either with or without FGF2. The osteogenic medium was supplemented with dexamethasone (DXM), $\beta$-glycerophosphate (BGCP), ascorbic acid (AA), variably also with L-glutamin (L-GLU) and vitamin D3 (for details of the composition see Table 3). The basal medium without osteogenic supplements was used as a control. The cells were cultured for 27 days. On days 6 , 13, 20, and 27, we performed a resazurin assay, 
Table 3. Composition of the culture media (A-I) used in our experiment.

\begin{tabular}{lccccccccc}
\hline Medium & A & B & C & D & E & F & G & H & I \\
\hline$D M E M+10 \% \mathrm{FS}$ & + & + & + & + & + & + & + & + & + \\
$F G F 2(5$ or $10 \mathrm{ng} / \mathrm{ml})$ & - & - & - & $10 \mathrm{ng}$ & $10 \mathrm{ng}$ & $10 \mathrm{ng}$ & $5 \mathrm{ng}$ & $5 \mathrm{ng}$ & $5 \mathrm{ng}$ \\
$D X M(10 \mathrm{nM})$ & - & + & + & - & + & + & - & + & + \\
$B G C P(10 \mathrm{mM})$ & - & + & + & - & + & + & - & + & + \\
AA $(50 \mu \mathrm{g} / \mathrm{ml})$ & - & + & + & - & + & + & - & + & + \\
$L-G L U(2 \mathrm{mM})$ & - & - & + & - & - & + & - & - & + \\
$\operatorname{Vitamin} D 3(1 \mu M)$ & - & - & + & - & - & + & - & - & + \\
\hline
\end{tabular}

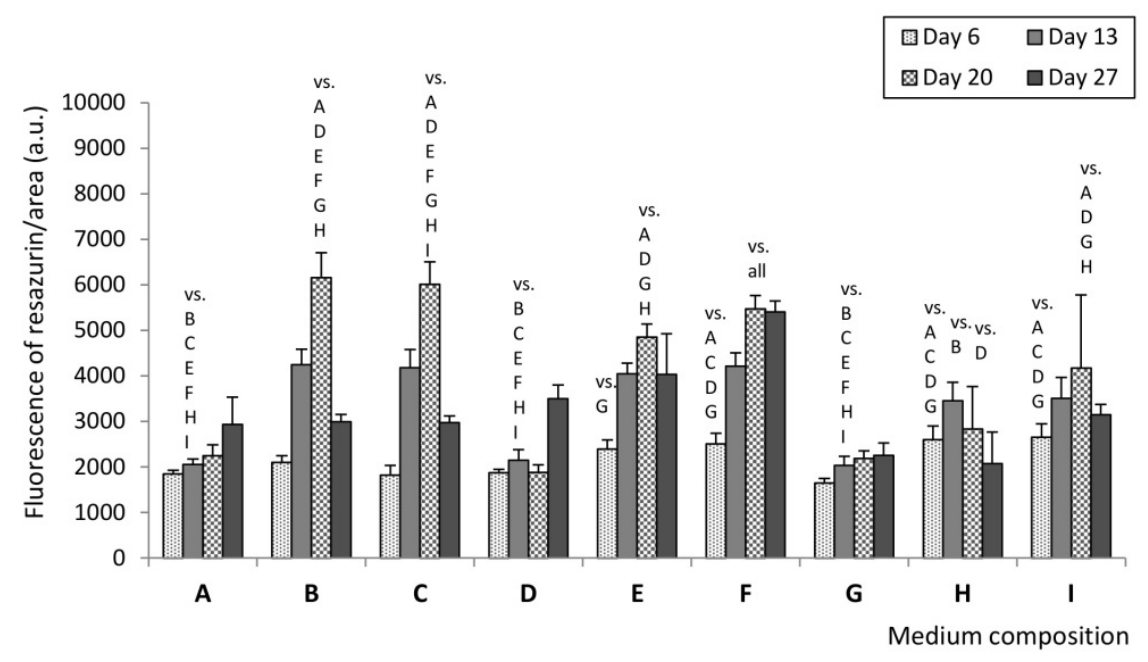

Fig. 2. The metabolic activity of ASCS cultured in media of different compositions (A-I) on day $6,13,20$, and 27 , measured by resazurin assay. A-C: without FGF2; D-F: supplemented with $10 \mathrm{ng} / \mathrm{ml}$ of FGF2; G-I: supplemented with $5 \mathrm{ng} / \mathrm{ml}$ of FGF2. A, D, G: without osteogenic supplements; B, $E, \quad H:$ supplemented with dexamethasone, $\beta$-glycero-phosphate, and ascorbic acid; C, F, I: also with L-glutamin and vitamin D3. The data is expressed as mean + SD. ANOVA, Student-Newman-Keuls method. The statistical significance $(p<0.05)$ is specified above the columns (in comparison with each sample on the same day of the culture).

an alkaline-phosphatase (ALP) activity assay, immunofluorescence staining of type I collagen and osteocalcin, and used the PCR method to detect gene expression of ALP and osteocalcin in order to evaluate the proliferation potential and osteogenic differentiation of ASCs.

Surprisingly, our results showed that the proliferation rate estimated by the metabolic activity of the cells, measured by a resazurin assay, depended more on the addition of osteogenic supplements than on the addition of FGF2 (Fig. 2). This tendency was also proved by counting the cell number in the same time intervals (data not shown). The activity of ALP, considered as an early or mid-term marker of osteogenic differentiation, was revealed to be significantly higher in cells cultivated without FGF2 during differentiation (Fig. 3). These results are in accordance with a study by Simann et al. (2017), where they observed a negative effect of FGFs on ALP expression. They also observed a negative correlation between FGF concentration and matrix mineralization. In our study, the gene expression of ALP increased in time. On day 6 and 13, the expression levels were higher in cells treated with osteogenic supplements without FGF2 (Fig. 4). Immunofluorescence staining revealed positive staining for both type I collagen and osteocalcin in cells treated with osteogenic supplements. On day 20, the highest gene expression of osteocalcin was measured in cells treated with osteogenic supplements and $5 \mathrm{ng} / \mathrm{ml}$ of FGF2 (Fig. 4), which was the same as for immunofluorescence staining (Fig. 5). The amount of calcium deposition on day 27 (data not shown) was also highest in the media with osteogenic supplements and $5 \mathrm{ng} / \mathrm{ml}$ of FGF2. These findings could suggest a potential benefit from lowering the FGF2 concentration during differentiation on late osteogenic markers. No significant benefit of a richer osteogenic medium (i.e. with L-GLU and vitamin D3) was observed in our study. The study was performed on ASCs from one patient. As discussed above, the proliferation and differentiation capacity of the cells may vary depending on patient factors. It would be impactful to apply this study to a larger number of ASCs from different patient donors, in order to see whether the tendency of the osteogenic markers is similar. 

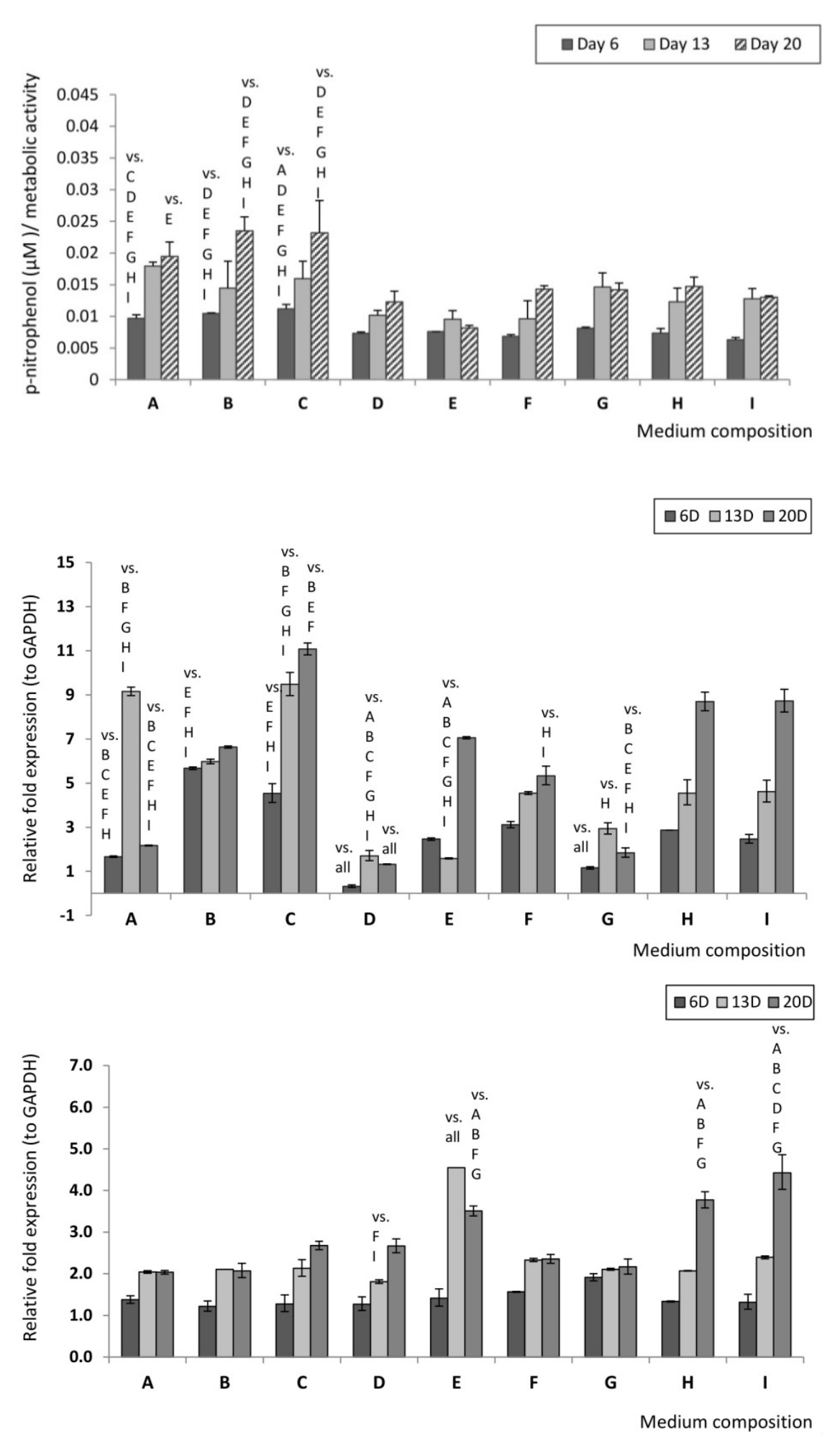

Fig. 3. The ALP activity of ASCS cultured in media of different compositions (A-I) on days 6,13 , and 20, measured by ALP assay. A-C without FGF2; D-F supplemented with $10 \mathrm{ng} / \mathrm{ml}$ of FGF2; G-I supplemented with $5 \mathrm{ng} / \mathrm{ml}$ of FGF2. A, D, G without osteogenic supplements; B, E, H supplemented with dexamethasone, $\beta$-glycerophosphate, and ascorbic acid; C, F, I also with L-glutamin and vitamin D3. The data is expressed as mean + SD. ANOVA, Student-NewmanKeuls method. Statistical significance $(p<0.05)$ is specified above the columns (in comparison with each sample on the same day of the culture).

Fig. 4. Gene expression of ALP (upper panel) and osteocalcin (lower panel) in ASCs cultured in media of different compositions (A-I) on days 6,13 , and 20, measured by real-time Q-PCR. A-C without FGF2; D-F supplemented with $10 \mathrm{ng} / \mathrm{ml}$ of FGF2; G-I supplemented with $5 \mathrm{ng} / \mathrm{ml}$ of FGF2. A, D, G without osteogenic supplements; B, E, H supplemented with dexamethasone, $\beta$-glycerophosphate, and ascorbic acid; C, F, I also with L-glutamin and vitamin D3. The data is expressed as mean \pm SD. ANOVA, StudentNewman-Keuls method. Statistical significance $(p<0.001)$ is specified above the columns (in comparison with each sample on the same day of the culture).

\section{Conclusions}

Tissue engineering is a very promising field for current and future regenerative medicine. The incidence of degenerative disorders correlates positively with increasing life expectancy. Tissue engineering research has clarified many molecular pathways, new sources of stem cells, new functional biomaterials and potential clinical applications in recent years. However, there are still many ambiguous factors that hamper efforts to ensure safer clinical applications. Adult mesenchymal stem cells have a great potential to be a basic cellular component of tissue replacements, thanks to the large number of advantages discussed in this review. However, the proliferation and differentiation abilities of stem cells are directly dependent on the static and dynamic culture 

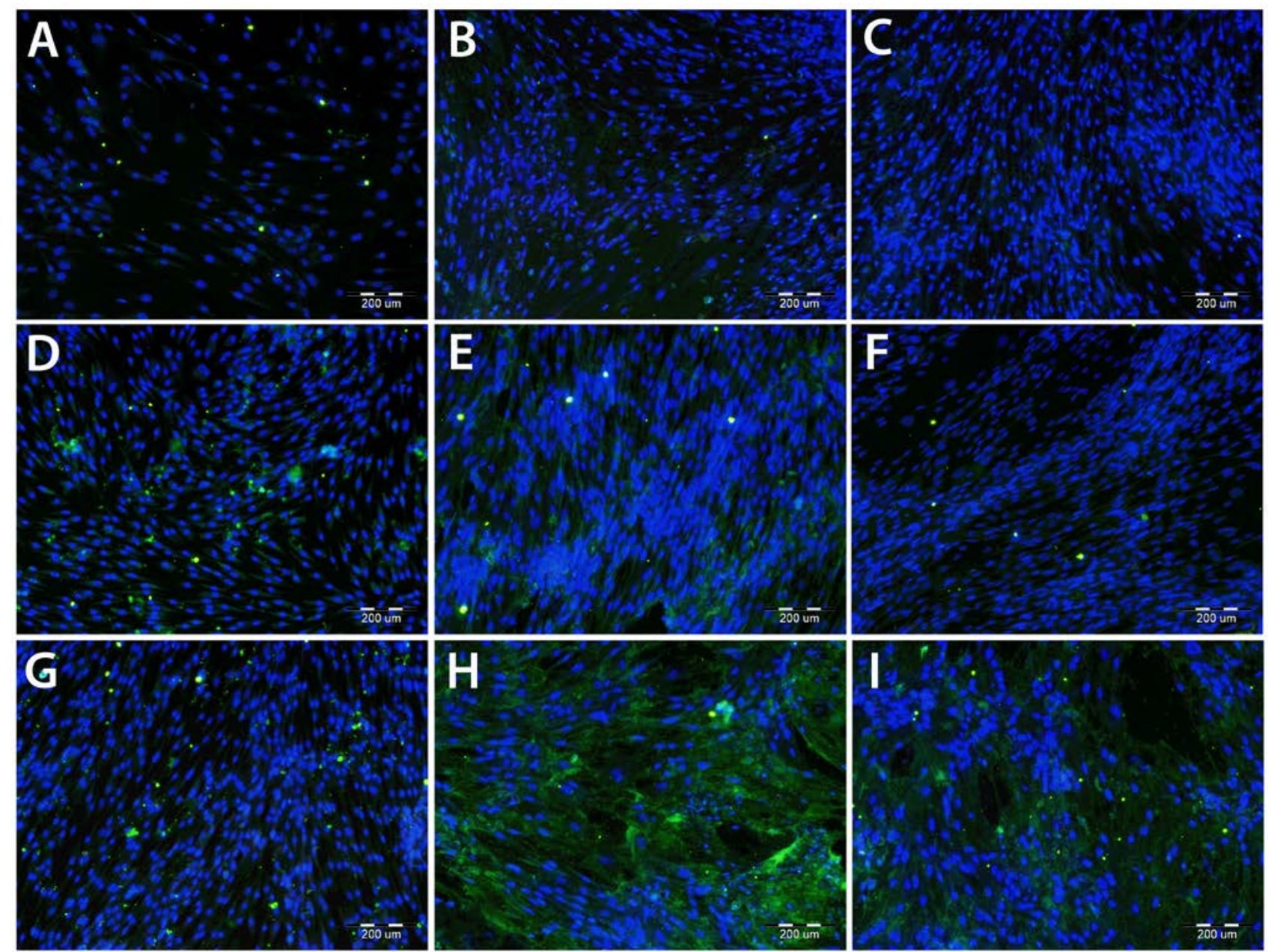

Fig. 5. The immuno-fluorescence staining of osteocalcin (green) and cell nuclei (blue) in ASCs cultured in media of different compositions (A-I) on day 20. A-C without FGF2; D-F supplemented with $10 \mathrm{ng} / \mathrm{ml}$ of FGF2; G-I supplemented with $5 \mathrm{ng} / \mathrm{ml}$ of FGF2. A, D, G without osteogenic supplements; B, E, H supplemented with dexamethasone, $\beta$-glycerophosphate, and ascorbic acid; C, F, I also with L-glutamin and vitamin D3. Olympus IX 71 microscope, objective $\times 10$, scale $200 \mu \mathrm{m}$, exposure time 1,500 ms.

conditions, on the properties of the biomaterial, and on the type of in vivo applications. Moreover, the properties of stem cells are not uniform, and can vary among patients. All these factors are very important, and can influence subsequent clinical applications. Some differences among patient donors have already been reported, but there remains a huge need to perform larger studies to optimize procedures for further clinical use.

\section{Conflict of Interest}

There is no conflict of interest.

\section{Acknowledgements}

This work was supported by the Grant Agency of Charles
University (GAUK, project No. 642217), by the Ministry of Education, Youth and Sports of the Czech Republic within LQ1604 National Sustainability Program II (Project BIOCEV-FAR), and by the Czech Health Research Council, Ministry of Health of the Czech Republic (grant No. 15-33018A). The authors would like to thank Dr. Martin Molitor (Hospital Na Bulovce) for adipose tissue and Dr. Marta Vandrovcova (Institute of Physiology of the Czech Academy of Sciences) for the experiment planning. Mr. Robin Healey (Czech Technical University in Prague) is gratefully acknowledged for his language revision of the manuscript.

\section{References}

ALARIBE FN, MANOTO SL, MOTAUNG SCKM: Scaffolds from biomaterials: advantages and limitations in bone and tissue engineering. Biologia 71: 353-366, 2016. 
ARVIDSON K, ABDALLAH BM, APPLEGATE LA, BALDINI N, CENNI E, GOMEZ-BARRENA E, GRANCHI D, KASSEM M, KONTTINEN YT, MUSTAFA K, PIOLETTI DP, SILLAT T, FINNE-WISTRAND A: Bone regeneration and stem cells. J Cell Mol Med 15: 718-746, 2011.

ASAHARA T, KALKA C, ISNER JM: Stem cell therapy and gene transfer for regeneration. Gene Ther 7: 451-457, 2000.

ATALA A: Tissue engineering, stem cells and cloning: current concepts and changing trends. Expert Opin Biol Ther 5: 879-892, 2005.

AWAD HA, WICKHAM MQ, LEDDY HA, GIMBLE JM, GUILAK F: Chondrogenic differentiation of adiposederived adult stem cells in agarose, alginate, and gelatin scaffolds. Biomaterials 25: 3211-3222, 2004.

BAČÁKOVÁ L, NOVOTNÁ K, PAŘíZEK M: Polysaccharides as cell carriers for tissue engineering: the use of cellulose in vascular wall reconstruction. Physiol Res 63 (Suppl 1): S29-S47, 2014.

BACAKOVA L, ZARUBOVA J, TRAVNICKOVA M, MUSILKOVA J, PAJOROVA J, SLEPICKA P, KASALKOVA NS, SVORCIK V, KOLSKA Z, MOTARJEMI H, MOLITOR M: Stem cells: their source, potency and use in regenerative therapies with focus on adipose-derived stem cells - a review. Biotechnol Adv 36: 1111-1126, 2018.

BADYLAK SF: Xenogeneic extracellular matrix as a scaffold for tissue reconstruction. Transpl Immunol 12: 367-377, 2004.

BALLEN KK, GLUCKMAN E, BROXMEYER HE: Umbilical cord blood transplantation: the first 25 years and beyond. Blood 122: 491-498, 2013.

BANAS A, TERATANI T, YAMAMOTO Y, TOKUHARA M, TAKESHITA F, OSAKI M, KATO T, OKOCHI H, OCHIYA T: Rapid hepatic fate specification of adipose-derived stem cells and their therapeutic potential for liver failure. J Gastroenterol Hepatol 24: 70-77, 2009.

BANYARD DA, SALIBIAN AA, WIDGEROW AD, EVANS GRD: Implications for human adipose-derived stem cells in plastic surgery. $J$ Cell Mol Med 19: 21-30, 2015.

BARISAS DAG, STAPPENBECK TS: Intestinal stem cells live off the fat of the land. Cell Stem Cell 22: 611-612, 2018.

BASSI ÊJ, MORAES-VIEIRA PM, MOREIRA-SÁ CS, ALMEIDA DC, VIEIRA LM, CUNHA CS, HIYANE MI, BASSO AS, PACHECO-SILVA A, CÂMARA NO: Immune regulatory properties of allogeneic adiposederived mesenchymal stem cells in the treatment of experimental autoimmune diabetes. Diabetes 61: 2534-2545, 2012.

BEN-DAVID U, BENVENISTY N: The tumorigenicity of human embryonic and induced pluripotent stem cells. Nat Rev Cancer 11: 268-277, 2011.

BISSELS U, DIENER Y, ECKARDT D, BOSIO A: Characterization and classification of stem cells. In: Regenerative Medicine - from Protocol to Patient, 2. Stem Cell Science and Technology. STEINHOFF G (ed.), Springer International Publishing AG Switzerland, 2016, pp 1-25.

BONEWALD LF, MUNDY GR: Role of transforming growth factor-beta in bone remodeling. Clin Orthop Relat Res (250): 261-276, 1990.

BOURIN P, BUNNELL BA, CASTEILLA L, DOMINICI M, KATZ AJ, MARCH KL, REDL H, RUBIN JP, YOSHIMURA K, GIMBLE JM: Stromal cells from the adipose tissue-derived stromal vascular fraction and culture expanded adipose tissue-derived stromal/stem cells: a joint statement of the International Federation for Adipose Therapeutics and Science (IFATS) and the International Society for Cellular Therapy (ISCT). Cytotherapy 15: 641-648, 2013.

BRANDT KD, DIEPPE P, RADIN EL: Etiopathogenesis of osteoarthritis. Rheum Dis Clin North Am 34: 531-559, 2008.

BRENNER CH, DAVID R, FRANZ WM: Stem cells for cardiovascular regeneration. In: Regenerative Medicine from Protocol to Patient, 2. Stem Cell Science and Technology. STEINHOFF G (ed.), Springer International Publishing AG Switzerland, 2016, pp 145-167. 
BRUN J, LUTZ KA, NEUMAYER KM, KLEIN G, SEEGER T, UYNUK-OOL T, WÖRGÖTTER K, SCHMID S, KRAUSHAAR U, GUENTHER E, ROLAUFFS B, AICHER WK, HART ML: Smooth muscle-like cells generated from human mesenchymal stromal cells display marker gene expression and electrophysiological competence comparable to bladder smooth muscle cells. PLoS One 10: e0145153, 2015.

BRUNSTEIN CG, WAGNER JE: Umbilical cord blood transplantation and banking. Annu Rev Med 57: 403-417, 2006. CAPLAN AI: Mesenchymal stem cells. J Orthop Res 9: 641-650, 1991.

CAPLAN AI: Mesenchymal stem cells: time to change the name! Stem Cells Transl Med 6: 1445-1451, 2017.

CHEN C, HAN X, FAN F, LIU Y, WANG T, WANG J, HU P, MA A, TIAN H: Serotonin drives the activation of pulmonary artery adventitial fibroblasts and TGF- $\beta 1 /$ Smad3-mediated fibrotic responses through 5 -HT(2A) receptors. Mol Cell Biochem 397: 267-276, 2014.

CHEN L, TREDGET EE, WU PY, WU Y: Paracrine factors of mesenchymal stem cells recruit macrophages and endothelial lineage cells and enhance wound healing. PLoS One 3: e1886, 2008.

CHEN Q, THOUAS GA: Metallic implant biomaterials. Mater Sci Eng R 87: 1-57, 2015.

CHEN YW, WANG JR, LIAO X, LI SH, XIAO LL, CHENG B, XIE GH, SONG JX, LIU HW: Effect of suction pressures on cell yield and functionality of the adipose-derived stromal vascular fraction. $J$ Plast Reconstr Aesthet Surg 70: 257-266, 2017.

CHLUPÁČ J, FILOVÁ E, BAČÁKOVÁ L: Blood vessel replacement: 50 years of development and tissue engineering paradigms in vascular surgery. Physiol Res 58 (Suppl 2): S119-S139, 2009.

CLARKE B: Normal bone anatomy and physiology. Clin J Am Soc Nephrol 3 (Suppl 3): S131-S139, 2008.

COLLAWN SS, BANERJEE NS, DE LA TORRE J, VASCONEZ L, CHOW LT: Adipose-derived stromal cells accelerate wound healing in an organotypic raft culture model. Ann Plast Surg 68: 501-504, 2012.

COOPER TP, SEFTON MV: Fibronectin coating of collagen modules increases in vivo HUVEC survival and vessel formation in SCID mice. Acta Biomater 7: 1072-1083, 2011.

CORSELLI M, CHEN CW, SUN B, YAP S, RUBIN JP, PÉAULT B: The tunica adventitia of human arteries and veins as a source of mesenchymal stem cells. Stem Cells Dev 21: 1299-1308, 2012.

DAWSON E, MAPILI G, ERICKSON K, TAQVI S, ROY K: Biomaterials for stem cell differentiation. Adv Drug Deliv Rev 60: 215-228, 2008.

DE FRANCESCO EM, SOTGIA F, LISANTI MP: Cancer stem cells (CSCs): metabolic strategies for their identification and eradication. Biochem J 475: 1611-1634, 2018.

DI SUMMA PG, KINGHAM PJ, RAFFOUL W, WIBERG M, TERENGHI G, KALBERMATTEN DF: Adiposederived stem cells enhance peripheral nerve regeneration. J Plast Reconstr Aesthet Surg 63: 1544-1552, 2010.

ESPOSITO MT: Blood factory: which stem cells? BMC Hematol 18: 10, 2018.

ESTES BT, DIEKMAN BO, GIMBLE JM, GUILAK F: Isolation of adipose-derived stem cells and their induction to a chondrogenic phenotype. Nat Protoc 5: 1294-1311, 2010.

FAGER G, HANSSON GK, GOWN AM, LARSON DM, SKALLI O, BONDJERS G: Human arterial smooth muscle cells in culture: inverse relationship between proliferation and expression of contractile proteins. In Vitro Cell Dev Biol 25: 511-520, 1989.

FILOVÁ E, BRYNDA E, RIEDEL T, CHLUPÁČ J, VANDROVCOVÁ M, SVINDRYCH Z, LISÁ V, HOUSKA M, PIRK J, BAČÁKOVÁ L: Improved adhesion and differentiation of endothelial cells on surface-attached fibrin structures containing extracellular matrix proteins. J Biomed Mater Res A 102: 698-712, 2014.

FRESE L, DIJKMAN PE, HOERSTRUP SP: Adipose tissue-derived stem cells in regenerative medicine. Transfus Med Hemother 43: 268-274, 2016.

GARCÍA-GARETA E, COATHUP MJ, BLUNN GW: Osteoinduction of bone grafting materials for bone repair and regeneration. Bone 81: 112-121, 2015.

GASKELL T, MIKAEL COE, HYLLNER J: Human embryonic stem cells. In: Regenerative Medicine - from Protocol to Patient, 2. Stem Cell Science and Technology. STEINHOFF G (ed.), Springer International Publishing AG Switzerland, 2016, pp 27-49.

GIMBRONE MA JR, GARCÍA-CARDEÑA G: Endothelial cell dysfunction and the pathobiology of atherosclerosis. Circ Res 118: 620-636, 2016. 
GNECCHI M, ZHANG Z, NI A, DZAU VJ: Paracrine mechanisms in adult stem cell signaling and therapy. Circ Res 103: 1204-1219, 2008.

GONZALEZ MA, GONZALEZ-REY E, RICO L, BÜSCHER D, DELGADO M: Adipose-derived mesenchymal stem cells alleviate experimental colitis by inhibiting inflammatory and autoimmune responses. Gastroenterology 136: 978-989, 2009.

GONZALEZ-REY E, GONZALEZ MA, VARELA N, O'VALLE F, HERNANDEZ-CORTES P, RICO L, BÜSCHER D, DELGADO M: Human adipose-derived mesenchymal stem cells reduce inflammatory and $\mathrm{T}$ cell responses and induce regulatory T cells in vitro in rheumatoid arthritis. Ann Rheum Dis 69: 241-248, 2010.

HARRIS LJ, ABDOLLAHI H, ZHANG P, MCILHENNY S, TULENKO T, DIMUZIO PJ: Differentiation of adult stem cells into smooth muscle for vascular tissue engineering. J Surg Res 168: 306-314, 2011.

HE J, LI X, LUO H, LI T, ZHAO L, QI Q, LIU Y, YU Z: Galectin-3 mediates the pulmonary arterial hypertensioninduced right ventricular remodeling through interacting with NADPH oxidase 4. J Am Soc Hypertens 11: 275-289.e2, 2017.

HEIJINK A, GOMOLL AH, MADRY H, DROBNIČ M, FILARDO G, ESPREGUEIRA-MENDES J, VAN DIJK CN: Biomechanical considerations in the pathogenesis of osteoarthritis of the knee. Knee Surg Sports Traumatol Arthrosc 20: 423-435, 2012.

HINKEN AC, BILLIN AN: Isolation of skeletal muscle stem cells for phenotypic screens for modulators of proliferation. Methods Mol Biol 1787: 77-86, 2018.

https://www.clinicaltrials.gov

HU F, WANG X, LIANG G, LV L, ZHU Y, SUN B, XIAO Z: Effects of epidermal growth factor and basic fibroblast growth factor on the proliferation and osteogenic and neural differentiation of adipose-derived stem cells. Cell Reprogram 15: 224-232, 2013.

IGURA K, ZHANG X, TAKAHASHI K, MITSURU A, YAMAGUCHI S, TAKASHI TA: Isolation and characterization of mesenchymal progenitor cells from chorionic villi of human placenta. Cytotherapy 6: 543-553, 2004.

IN'T ANKER PS, SCHERJON SA, KLEIJBURG-VAN DER KEUR C, NOORT WA, CLAAS FH, WILLEMZE R, FIBBE WE, KANHAI HH: Amniotic fluid as a novel source of mesenchymal stem cells for therapeutic transplantation. Blood 102: 1548-1549, 2003.

IN'T ANKER PS, SCHERJON SA, KLEIJBURG-VAN DER KEUR C, DE GROOT-SWINGS GM, CLAAS FH, FIBBE WE, KANHAI HH: Isolation of mesenchymal stem cells of fetal or maternal origin from human placenta. Stem Cells 22: 1338-1345, 2004.

JIN SE, SUNG JH: Hair regeneration using adipose-derived stem cells. Histol Histopathol 31: 249-256, 2016.

KANNAN RY, SALACINSKI HJ, BUTLER PE, HAMILTON G, SEIFALIAN AM: Current status of prosthetic bypass grafts: a review. J Biomed Mater Res B Appl Biomater 74: 570-581, 2005.

KERN S, EICHLER H, STOEVE J, KLÜTER H, BIEBACK K: Comparative analysis of mesenchymal stem cells from bone marrow, umbilical cord blood, or adipose tissue. Stem Cells 24: 1294-1301, 2006.

KIM JW, KIM SY, PARK SY, KIM YM, KIM JM, LEE MH, RYU HM: Mesenchymal progenitor cells in the human umbilical cord. Ann Hematol 83: 733-738, 2004.

KIM MR, JEON ES, KIM YM, LEE JS, KIM JH: Thromboxane a(2) induces differentiation of human mesenchymal stem cells to smooth muscle-like cells. Stem Cells 27: 191-199, 2009.

KLOPSCH C, SKORSKA A, LUDWIG M, GAEBEL R, LEMCKE H, KLEINER G, BEYER M, VOLLMAR B, DAVID R, STEINHOFF G: Cardiac mesenchymal stem cells proliferate early in the ischemic heart. Eur Surg Res 58: 341-353, 2017.

KODET O, DVOŘÁNKOVÁ B, BENDLOVÁ B, SÝKOROVÁ V, KRAJSOVÁ I, ŠTORK J, KUČERA J, SZABO P, STRNAD H, KOLÁŘ M, VLČEK Č, SMETANA K JR, LACINA L: Microenvironment driven resistance to B Raf inhibition in a melanoma patient is accompanied by broad changes of gene methylation and expression in distal fibroblasts. Int J Mol Med 41: 2687-2703, 2018. 
KÖGLER G, SENSKEN S, AIREY JA, TRAPP T, MÜSCHEN M, FELDHAHN N, LIEDTKE S, SORG RV, FISCHER J, ROSENBAUM C, GRESCHAT S, KNIPPER A, BENDER J, DEGISTIRICI O, GAO J, CAPLAN AI, COLLETTI EJ, ALMEIDA-PORADA G, MÜLLER HW, ZANJANI E, WERNET P: A new human somatic stem cell from placental cord blood with intrinsic pluripotent differentiation potential. $J$ Exp Med 200: 123-135, 2004.

KOJIMA Y, ACAR A, EATON EN, MELLODY KT, SCHEEL C, BEN-PORATH I, ONDER TT, WANG ZC, RICHARDSON AL, WEINBERG RA, ORIMO A: Autocrine TGF-beta and stromal cell-derived factor-1 (SDF-1) signaling drives the evolution of tumor-promoting mammary stromal myofibroblasts. Proc Natl Acad Sci U S A 107: 20009-20014, 2010.

KUTZNER I, HEINLEIN B, GRAICHEN F, BENDER A, ROHLMANN A, HALDER A, BEIER A, BERGMANN G: Loading of the knee joint during activities of daily living measured in vivo in five subjects. $J$ Biomech 43: 2164-2173, 2010.

LAFYATIS R: Transforming growth factor $\beta$ - at the centre of systemic sclerosis. Nat Rev Rheumatol 10: 706-719, 2014.

LENDECKEL S, JÖDICKE A, CHRISTOPHIS P, HEIDINGER K, WOLFF J, FRASER JK, HEDRICK MH, BERTHOLD L, HOWALDT HP: Autologous stem cells (adipose) and fibrin glue used to treat widespread traumatic calvarial defects: case report. J Craniomaxillofac Surg 32: 370-373, 2004.

LEON L, GREISLER HP: Vascular grafts. Expert Rev Cardiovasc Ther 1: 581-594, 2003.

LEVI B, LONGAKER MT: Concise review: adipose-derived stromal cells for skeletal regenerative medicine. Stem Cells 29: 576-582, 2011.

LI J, MARTIN EC, GIMBLE JM: Adipose-derived stem/stromal cells. In: Regenerative Medicine - from Protocol to Patient, 2. Stem Cell Science and Technology. STEINHOFF G (ed.), Springer International Publishing AG Switzerland, 2016, pp 363-387.

LIAO HT, CHEN CHT: Osteogenic potential: comparison between bone marrow and adipose-derived mesenchymal stem cells. World J Stem Cells 6: 288-295, 2014.

LIM S, CHO H, LEE E, WON Y, KIM C, AHN W, LEE E, SON Y: Osteogenic stimulation of human adipose-derived stem cells by pre-treatment with fibroblast growth factor 2. Cell Tissue Res 364: 137-147, 2016.

LIN G, WANG G, LIU G, YANG LJ, CHANG LJ, LUE TF, LIN CS: Treatment of type 1 diabetes with adipose tissuederived stem cells expressing pancreatic duodenal homeobox 1. Stem Cells Dev 18: 1399-1406, 2009.

LOESER RF, COLLINS JA, DIEKMAN BO: Ageing and the pathogenesis of osteoarthritis. Nat Rev Rheumatol 12: 412-420, 2016.

MADONNA R, DE CATERINA R: Adipose tissue: a new source for cardiovascular repair. J Cardiovasc Med (Hagerstown) 11: 71-80, 2010.

MAN GS, MOLOGHIANU G: Osteoarthritis pathogenesis - a complex process that involves the entire joint. $J$ Med Life 7: 37-41, 2014.

MARTIN TJ, SEEMAN E: Bone remodelling: its local regulation and the emergence of bone fragility. Best Pract Res Clin Endocrinol Metab 22: 701-722, 2008.

MCCUE S, DAJNOWIEC D, XU F, ZHANG M, JACKSON MR, LANGILLE BL: Shear stress regulates forward and reverse planar cell polarity of vascular endothelium in vivo and in vitro. Circ Res 98: 939-946, 2006.

MEINEL L, FAJARDO R, HOFMANN S, LANGER R, CHEN J, SNYDER B, VUNJAK-NOVAKOVIC G, KAPLAN D: Silk implants for the healing of critical size bone defects. Bone 37: 688-698, 2005.

MERFELD-CLAUSS S, GOLLAHALLI N, MARCH KL, TRAKTUEV DO: Adipose tissue progenitor cells directly interact with endothelial cells to induce vascular network formation. Tissue Eng Part A 16: 2953-2966, 2010.

MOJALLAL A, AUXENFANS C, LEQUEUX C, BRAYE F, DAMOUR O: Influence of negative pressure when harvesting adipose tissue on cell yield of the stromal-vascular fraction. Biomed Mater Eng 18: 193-197, 2008.

MURPHY SV, ATALA A: Organ engineering - combining stem cells, biomaterials, and bioreactors to produce bioengineered organs for transplantation. Bioessays 35: 163-172, 2013.

MURPHY WL, MCDEVITT TC, ENGLER AJ: Materials as stem cell regulators. Nat Mater 13: 547-557, 2014. 
NARITA Y, YAMAWAKI A, KAGAMI H, UEDA M, UEDA Y: Effects of transforming growth factor-beta 1 and ascorbic acid on differentiation of human bone-marrow-derived mesenchymal stem cells into smooth muscle cell lineage. Cell Tissue Res 333: 449-459, 2008.

O’BRIEN FJ: Biomaterials \& scaffolds for tissue engineering. Materialstoday 14: 88-95, 2011.

O'DONOGHUE K, FISK NM: Fetal stem cells. Best Pract Res Clin Obstet Gynaecol 18: 853-875, 2004.

OJEH N, PASTAR I, TOMIC-CANIC M, STOJADINOVIC O: Stem cells in skin regeneration, wound healing, and their clinical applications. Int J Mol Sci 16: 25476-25501, 2015.

PAK J, LEE JH, PARK KS, PARK M, KANG LW, LEE SH: Current use of autologous adipose tissue-derived stromal vascular fraction cells for orthopedic applications. J Biomed Sci 24: 9, 2017.

PARK JB: Effects of the combination of dexamethasone and fibroblast growth factor 2 on differentiation of osteoprecursor cells. Mol Med Rep 9: 659-662, 2014.

PAULI C, GROGAN SP, PATIL S, OTSUKI S, HASEGAWA A, KOZIOL J, LOTZ MK, D'LIMA DD: Macroscopic and histopathologic analysis of human knee menisci in aging and osteoarthritis. Osteoarthritis Cartilage 19: 1132-1141, 2011.

PITTENGER MF, MACKAY AM, BECK SC, JAISWAL RK, DOUGLAS R, MOSCA JD, MOORMAN MA, SIMONETTI DW, CRAIG S, MARSHAK DR: Multilineage potential of adult human mesenchymal stem cells. Science 284: 143-147, 1999.

POMETLOVÁ M, NOHEJLOVÁ K, BERNÁŠKOVÁ K: Fyziologie a patofyziologie oběhového systému. In: Fyziologie a patologická fyziologie pro klinickou praxi. R ROKYTA et al. (eds), GRADA Publishing, 2015, pp 123-183.

PRZEKORA A, VANDROVCOVA M, TRAVNICKOVA M, PAJOROVA J, MOLITOR M, GINALSKA G, BACAKOVA L: Evaluation of the potential of chitosan/ $\beta$-1,3-glucan/hydroxyapatite material as a scaffold for living bone graft production in vitro by comparison of ADSC and BMDSC behaviour on its surface. Biomed Mater 12: 015030, 2017.

QUINT C, ARIEF M, MUTO A, DARDIK A, NIKLASON LE: Allogeneic human tissue-engineered blood vessel. J Vasc Surg 55: 790-798, 2012.

RAVI S, QU Z, CHAIKOF EL: Polymeric materials for tissue engineering of arterial substitutes. Vascular 17 (Suppl 1): S45-S54, 2009.

REICHERT JC, NOTH U, BERNER A, HUTMACHER DW: Bone. In: Regenerative Medicine - from Protocol to Patient, 5. Regenerative Therapies II. STEINHOFF G (ed.), Springer International Publishing AG Switzerland, 2016, pp 289-304.

RIGGS JW, BARRILLEAUX BL, VARLAKHANOVA N, BUSH KM, CHAN V, KNOEPFLER PS: Induced pluripotency and oncogenic transformation are related processes. Stem Cells Dev 22: 37-50, 2013.

ROBERTS RL, SANDRA A: Apical-basal membrane polarity of membrane phosphatases in isolated capillary endothelium: alteration in ultrastructural localisation under culture conditions. J Anat 182: 339-347, 1993.

ROTHDIENER M, HEGEMANN M, UYNUK-OOL T, WALTERS B, PAPUGY P, NGUYEN P, CLAUS V, SEEGER T, STOECKLE U, BOEHME KA, AICHER WK, STEGEMANN JP, HART ML, KURZ B, KLEIN G, ROLAUFFS B: Stretching human mesenchymal stromal cells on stiffness-customized collagen type I generates a smooth muscle marker profile without growth factor addition. Sci Rep 6: 35840, 2016.

SAINI M, SINGH Y, ARORA P, ARORA V, JAIN K: Implant biomaterials: A comprehensive review. World J Clin Cases 3: 52-57, 2015.

SALGADO AJ, REIS RL, SOUSA NJ, GIMBLE JM: Adipose tissue derived stem cells secretome: soluble factors and their roles in regenerative medicine. Curr Stem Cell Res Ther 5: 103-110, 2010.

SGARIOTO M, VIGNERON P, PATTERSON J, MALHERBE F, NAGEL MD, EGLES C: Collagen type I together with fibronectin provide a better support for endothelialization. C R Biol 335: 520-528, 2012.

SHIMIZU N, YAMAMOTO K, OBI S, KUMAGAYA S, MASUMURA T, SHIMANO Y, NARUSE K, YAMASHITA JK, IGARASHI T, ANDO J: Cyclic strain induces mouse embryonic stem cell differentiation into vascular smooth muscle cells by activating PDGF receptor beta. J Appl Physiol 104: 766-772, 2008. 
SIMANN M, LE BLANC S, SCHNEIDER V, ZEHE V, LÜDEMANN M, SCHÜTZE N, JAKOB F, SCHILLING T: Canonical FGFs prevent osteogenic lineage commitment and differentiation of human bone marrow stromal cells via ERK1/2 signaling. J Cell Biochem 118: 263-275, 2017.

SINGER NG, CAPLAN AI: Mesenchymal stem cells: mechanisms of inflammation. Annu Rev Pathol 6: 457-478, 2011.

STANKO P, ALTANEROVA U, JAKUBECHOVA J, REPISKA V, ALTANER C: Dental mesenchymal stem/stromal cells and their exosomes. Stem Cells Int 2018: 8973613, 2018.

STREM BM, HICOK KC, ZHU M, WULUR I, ALFONSO Z, SCHREIBER RE, FRASER JK, HEDRICK MH: Multipotential differentiation of adipose tissue-derived stem cells. Keio J Med 54: 132-141, 2005.

STRONG AL, BOWLES AC, MACCRIMMON CP, FRAZIER TP, LEE SJ, WU X, KATZ AJ, GAWRONSKAKOZAK B, BUNNELL BA, GIMBLE JM: Adipose stromal cells repair pressure ulcers in both young and elderly mice: potential role of adipogenesis in skin repair. Stem Cells Transl Med 4: 632-642, 2015.

SUN J, TAN H: Alginate-based biomaterials for regenerative medicine applications. Materials 6: 1285-1309, 2013.

SUNG HJ, ESKIN SG, SAKURAI Y, YEE A, KATAOKA N, MCINTIRE LV: Oxidative stress produced with cell migration increases synthetic phenotype of vascular smooth muscle cells. Ann Biomed Eng 33: 1546-1554, 2005.

TAKAHASHI K, YAMANAKA S: Induction of pluripotent stem cells from mouse embryonic and adult fibroblast cultures by defined factors. Cell 126: 663-676, 2006.

TAPIAS LF, OTT HC: Decellularized scaffolds as a platform for bioengineered organs. Curr Opin Organ Transplant 19: 145-152, 2014.

TIRKKONEN L, HALONEN H, HYTTINEN J, KUOKKANEN H, SIEVÄNEN H, KOIVISTO AM, MANNERSTRÖM B, SÁNDOR GK, SUURONEN R, MIETTINEN S, HAIMI S: The effects of vibration loading on adipose stem cell number, viability and differentiation towards bone-forming cells. $J R$ Soc Interface 8: 1736-1747, 2011.

TORIO-PADRON N, HUOTARI AM, EISENHARDT SU, BORGES J, STARK GB: Comparison of pre-adipocyte yield, growth and differentiation characteristics from excised versus aspirated adipose tissue. Cells Tissues Organs 191: 365-371, 2010.

UCCELLI A, MORETTA L, PISTOIA V: Mesenchymal stem cells in health and disease. Nat Rev Immunol 8: 726-736, 2008.

VARGHESE J, GRIFFIN M, MOSAHEBI A, BUTLER P: Systematic review of patient factors affecting adipose stem cell viability and function: implications for regenerative therapy. Stem Cell Res Ther 8: 45, 2017.

VARMA MJ, BREULS RG, SCHOUTEN TE, JURGENS WJ, BONTKES HJ, SCHUURHUIS GJ, VAN HAM SM, VAN MILLIGEN FJ: Phenotypical and functional characterization of freshly isolated adipose tissue-derived stem cells. Stem Cells Dev 16: 91-104, 2007.

VATER C, KASTEN P, STIEHLER M: Culture media for the differentiation of mesenchymal stromal cells. Acta Biomater 7: 463-477, 2011.

VENKATRAMAN S, BOEY F, LAO LL: Implanted cardiovascular polymers: Natural, synthetic and bio-inspired. Prog Polym Sci 33: 853-874, 2008.

VIRJULA S, ZHAO F, LEIVO J, VANHATUPA S, KREUTZER J, VAUGHAN TJ, HONKALA AM, VIEHRIG M, MULLEN CA, KALLIO P, MCNAMARA LM, MIETTINEN S: The effect of equiaxial stretching on the osteogenic differentiation and mechanical properties of human adipose stem cells. J Mech Behav Biomed Mater 72: 38-48, 2017.

VON HEIMBURG D, HEMMRICH K, HAYDARLIOGLU S, STAIGER H, PALLUA N: Comparison of viable cell yield from excised versus aspirated adipose tissue. Cells Tissues Organs 178: 87-92, 2004.

WAKITANI S, IMOTO K, YAMAMOTO T, SAITO M, MURATA N, YONEDA M: Human autologous culture expanded bone marrow mesenchymal cell transplantation for repair of cartilage defects in osteoarthritic knees. Osteoarthritis Cartilage 10: 199-206, 2002.

WANG HS, HUNG SC, PENG ST, HUANG CC, WEI HM, GUO YJ, FU YS, LAI MC, CHEN CC: Mesenchymal stem cells in the Wharton's jelly of the human umbilical cord. Stem Cells 22: 1330-1337, 2004. 
WEI YC, CHEN F, ZHANG T, CHEN DY, JIA X, WANG JB, GUO W, CHEN J: Vascular smooth muscle cell culture in microfluidic devices. Biomicrofluidics 8: 046504, 2014.

WEISSMAN IL: Stem cells: units of development, units of regeneration, and units in evolution. Cell 100: 157-168, 2000.

WILLEMSE J, LIESHOUT R, VAN DER LAAN LJW, VERSTEGEN MMA: From organoids to organs: bioengineering liver grafts from hepatic stem cells and matrix. Best Pract Res Clin Gastroenterol 31: 151-159, 2017.

WU Y, CHEN L, SCOTT PG, TREDGET EE: Mesenchymal stem cells enhance wound healing through differentiation and angiogenesis: Stem Cells 25: 2648-2659, 2007.

WUCHTER P, WAGNER W, HO AD: Mesenchymal stromal cells (MSC). In: Regenerative Medicine - from Protocol to Patient, 2. Stem Cell Science and Technology. STEINHOFF G (ed.), Springer International Publishing AG Switzerland, 2016, pp 295-313.

YAMASAKI S, MERA H, ITOKAZU M, HASHIMOTO Y, WAKITANI S: Cartilage repair with autologous bone marrow mesenchymal stem cell transplantation: review of preclinical and clinical studies. Cartilage 5: 196-202, 2014.

YAÑEZ R, LAMANA ML, GARCÍA-CASTRO J, COLMENERO I, RAMÍREZ M, BUEREN JA: Adipose tissuederived mesenchymal stem cells have in vivo immunosuppressive properties applicable for the control of the graft-versus-host disease. Stem Cells 24: 2582-2591, 2006.

YANG SE, HA CW, JUNG M, JIN HJ, LEE M, SONG H, CHOI S, OH W, YANG YS: Mesenchymal stem/progenitor cells developed in cultures from UC blood. Cytotherapy 6: 476-486, 2004.

YOSHIMURA K, SATO K, AOI N, KURITA M, HIROHI T, HARII K: Cell-assisted lipotransfer for cosmetic breast augmentation: supportive use of adipose-derived stem/stromal cells. Aesthetic Plast Surg 32: 48-55, 2008.

ZHANG R, ZHANG Z, CHOPP M: Function of neural stem cells in ischemic brain repair processes. J Cereb Blood Flow Metab 36: 2034-2043, 2016.

ZHOU Y, GUAN X, ZHU Z, GAO S, ZHANG C, LI C, ZHOU K, HOU W, YU H: Osteogenic differentiation of bone marrow-derived mesenchymal stromal cells on bone-derived scaffolds: effect of microvibration and role of ERK1/2 activation. Eur Cell Mater 22: 12-25, 2011.

ZIMMERLIN L, DONNENBERG VS, PFEIFER ME, MEYER EM, PÉAULT B, RUBIN JP, DONNENBERG AD: Stromal vascular progenitors in adult human adipose tissue. Cytometry A 77: 22-30, 2010.

ZUK PA, ZHU M, MIZUNO H, HUANG J, FUTRELL JW, KATZ AJ, BENHAIM P, LORENZ HP, HEDRICK MH: Multilineage cells from human adipose tissue: implications for cell-based therapies. Tissue Eng 7: 211-228, 2001.

ZUK PA, ZHU M, ASHJIAN P, DE UQARTE DA, HUANG JI, MIZUNO H, ALFONSO ZC, FRASER JK, BENHAIM P, HEDRICK MH: Human adipose tissue is a source of multipotent stem cells. Mol Biol Cell 13: 4279-4295, 2002. 